\title{
Conservation in Madagascar
}

\author{
Darren Joneson* \\ Grant MacEwan University, Canada
}

\begin{abstract}
When most people hear the word Madagascar, images of animated dancing lemurs and quirky stranded penguins come to their minds. Although there is some truth in the movie's description of that far-away, mysterious place, it fails to paint a complete picture of Madagascar as being rich in biodiversity and culture. Few places on earth rival the variety of endemic plants and animals that are found there. It is estimated that Madagascar has more genetic diversity per unit area than anywhere else on earth (Karsten, et al., 2009). This makes it "one of the world's hottest hotspots for biodiversity conservation" (Consiglio, et al., 2006). Even though Madagascar is a biologically invaluable nation, it trails behind other ecologically notable countries, like Ecuador, in the conservation effort. Madagascar continues to suffer devastating loss to its precious habitats. The Madagascar government has the difficult task of preserving as much ecologically unique territory as it can, without depriving the already economically disadvantaged local people. Much international help is needed in providing support to the people and protection to the plants, animals, and natural resources of Madagascar.
\end{abstract}

\section{Biodiversity and Threats}

It is estimated that Madagascar has more genetic diversity per unit area than anywhere else on earth (Karsten, et al., 2009). This makes it "one of the world's hottest hotspots for biodiversity conservation" (Consiglio, et al., 2006). 


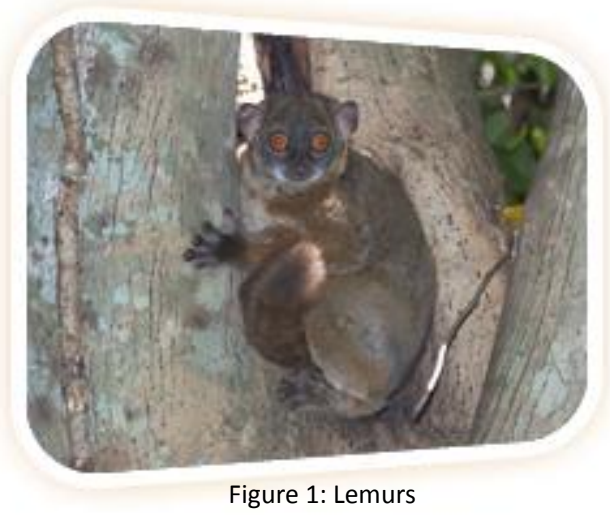

1980s, there were only six known species of lemurs on the island (Mittermeier, et al.). Now there are five families, and ninety-nine different species of lemur that have been recorded (Mittermeier, et al., 2008). That is one more primate family than exists in the entire continent of Africa, or the same amount of families as the Neotropics and Asia combined, all within an area 2-3\% the size of those regions (Mittermeier, et al., 2008). Unfortunately, only about $10 \%$, or about 50-60 thousand $\mathrm{km}^{2}$, of the island is a suitable habitat for these lemurs and that habitat is shrinking quickly (Mittermeier, et al., 2008).

Lemurs are not the only ones threatened by habitat loss. There are 220 species of amphibians in Madagascar, 55 of which are listed as endangered or threatened. Many of these amphibians are exported by the pet trade or are losing their habitat to deforestation (Andreone, et al., 2005). A large number of them live in eastern littoral forests which, in and of themselves, are also ecologically invaluable. These forests hold 176 species of palm trees--172 of which grow nowhere else on earth (Aguiar, 1998).

The Madagascar terrestrial and freshwater ecosystems are in danger. Deforestation leads to erosion, which in turn leads to high levels of sediment poured into rivers and streams. This can affect the water chemistry and threaten fresh water vertebrates. Benstead, et al. (2003) stated that protecting Madagascar freshwater ecosystems is extremely important for three reasons. First, there is much more diversity in the country's freshwater species than previously expected. Second, many of these species are only located in isolated areas of specific streams or rivers. Therefore, contamination of these small areas could quickly lead to a complete loss of the species. Third, many of these species are "phylogenetically basal taxa (i.e. Those species forming the earliest diverging group in their clade.)" (p. 1102). These fish species could be valuable for filling gaps in the fossil or contemporary record. In addition to erosion, many of these fish species suffer from over fishing, as well as are affected by the introduction of foreign fish species for aquaculture (Benstead, et al., 2003).

ECJ Volume 1, No. 1, 2011 
Fishing is important for both the income and health of coastal Malagasy people. Fish have a symbiotic relationship with the coral reefs in which they help maintain the health of the various coral reefs and in return receive food and protection from them. Unfortunately, in coastal and freshwater regions, the fishermen tend to use non-specific nets to catch prey. This non-selective form of fishing is wasteful which results in a high diversity of species being caught in the nets, few of which are considered inedible by the Malagasy people. Paradoxically, these unsustainable fishing practices are economically helping some Malagasy families rise above the poverty line; however, this type of economic aid is diminishing due to dwindling fish stocks which subsequently will affect these families' incomes (Davies, Beanjara, \& Tregenza, 2009).

\section{Government Intervention and the National Environmental Action Plan (NEAP)}

The government of Madagascar realizes the importance of the country's biodiversity and has taken steps to preserve some of its regions. The protected areas of the country are divided into three categories; complete natural reserves, national parks, and special reserves (Madagascar National Parks, 2010).

Complete natural reserves are known for their exceptional flora and fauna. The highest priority is given to preserving the pristine conditions of these areas. For this reason, tourists are not allowed to enter these areas (Madagascar National Parks, 2010).

Contrary to this approach, however, is that the national parks are also designed with tourists in mind, while still containing a wide array of plants and animals. In order to ensure that the parks are environmentally maintained, the national parks charge admission, and a guide is responsible for touring visitors throughout the area. Finally, there are the special reserves. These are designed and managed, as with all the other parks, with conservation as the primary goal. These parks are set aside because of the important species they contain, as well as their potential for future ecotourism (Madagascar National Parks, 2010).

Most reserves and parks are managed by the National Association of Protected Areas Management (ANGAP) while a few are overseen by the World Wildlife Fund (WWF). Through ANGAP and the Ministry of the Environment, Water, and Forests (MEWF) extensive effort has gone into planning for the protected areas of the country. As of 2008, there were 50 protected areas in Madagascar divided into parks and reserves approximating 3\% of the country's surface area (Rabearivony, et al., 2010). The five main objectives of these organizations for the parks are conservation, research and 
ecological monitoring, sustainable development, environmental education, and ecotourism (Ministère de l'Environnement, des Eaux et Forêts, 2003). In essence, ANGAP's main goal is to maximize the number of species they can protect in the minimum amount of land (Rabearivony, et al., 2010).

The major components of ANGAP's plan are outlined in the National Environment Action Plan (NEAP). The NEAP was implemented in three phases beginning in 1990. The major objectives of the first phase were to "reverse the downward spiral of environmental degradation, while promoting the sustainable use of natural resources and sustainable development" and to "create the necessary conditions to ensure that environmental considerations are fully integrated into all sectorial and macroeconomic programs within the country" (Ministère de l'Environnement, des Eaux et Forêts, 2003). In 1997, the second phase of the NEAP began. It consisted of four main components; direct specialized and operational components, transversal components, strategic components, and support components. The main objective for the direct specialized and operational components is to get local communities to take over natural resource management. Strategic components of NEAP are concerned with codes, legislation, and ensuring that international investment projects, like mines, are in environmentally acceptable areas. Finally, support components of NEAP focus on researching, training, and educating. In 2001, the third phase of the NEAP was implemented. It "has the overriding objective of ensuring the sustainability of environmental activities and their financial base" (Ministère de l'Environnement, des Eaux et Forêts, 2003).

\section{Geography and Ecology}

The NEAP is more than just objectives and phases, and the key to understanding its program is to understand the geography of the country.

The country of Madagascar is roughly the shape of your left foot; it spans $1000 \mathrm{~km}$ north-to-south, and $600 \mathrm{~km}$ east-to-west (Figure 2). It has six provinces and its ecology is separated into three main areas; the east coast and central highlands, the west coast, and the south. The central highlands contain the greatest number of inhabitants and are largely used for agriculture. Much of the land suffers from erosion because of the lack of vegetative cover due to

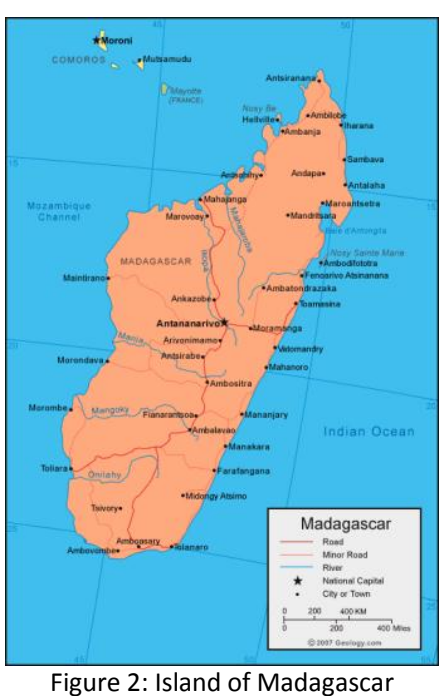

ECJ Volume 1, No. 1, 2011 
deforestation. Bare red soil can be seen in most places, which is where the country gets its name as the red island. The east coast forests are rich in biodiversity but they are being deforested at an alarming rate. Leaves are used for the thatching on roofs, and wood is used for construction. However, the most prominent devastation to the forests derives from the slash and burn practices that gather charcoal for fuel. Western Madagascar contains a wide variety of natural wonders including Tsingy National Park, which is a maze of razor sharp limestone spires, and the majestic Baobab trees. Southern Madagascar is the driest part of the country; one of its more interesting landscapes are the spiny forests (Ministère de l'Environnement, des Eaux et Forêts, 2003).

The NEAP has broken with the traditional geographical zoning of Madagascar, and instead has opted for protected land to fall under one of seven eco-regions; Northern highlands, Eastern, Center, High Mountains, Western, Southern, and Unique Isolated or Transitional Habitats (Ministère de l'Environnement, des Eaux et Forêts, 2003). Some of these eco-regions, their biodiversity, and the threats they face are discussed in more detail below.

The northern highlands are probably the most preserved area of Madagascar. This is due to the ruggedness of the terrain and the difficulty in accessing the area. In spite of this, only a little less than $40 \%$ of the area in the region contains its natural flora and fauna. About $20 \%$ of that area is within a protected zone. This area is rich in endemic arthropod, amphibian, reptile, and rodent species, and uniquely (for Madagascar), it does not contain any lemurs. Currently, the country sees no need for new parks in this area, only the possibility of expanding the area of its current parks (Ministère de l'Environnement, des Eaux et Forêts, 2003).

The eastern eco-region is in greater difficulty than the northern highlands. The eastern eco-region has a variety of different forests, but the most notable are its littoral forests. Littoral forests are unique in the fact that they can grow on sand and they have a great degree of plant biodiversity. The littoral forests of eastern Madagascar contain 13\% of Madagascar's plant species in less than $1 \%$ of its land area. Today, less than 50,000 hectares remain (Cosiglio, et al., 2006). In addition to the littoral forest, other forests of the east gradually transform from the central seasonal forests to the coastal humid forests (Ministère de l'Environnement, des Eaux et Forêts, 2003). This transformation is also evident in the architecture of the villages as you travel west-to-east. The huts slowly transform from brick, to brick and wood, and finally to completely wooden structures. Unfortunately, these forests are severely threatened by the very inhabitants of these huts. Consiglio, et al. (2006) note that there is "considerable pressure from local inhabitants in coastal villages for fuel, wood, and construction materials" (p. 1800). The villagers may 
be harming themselves in the long term, given that the eastern forests are also a protection from the seasonal cyclones that frequent Madagascar (Consiglio, et al., 2006).

The forests of the east are not the only areas affected by deforestation. This region is one of the most species-rich areas of Madagascar (Ministère de l'Environnement, des Eaux et Forêts, 2003). There is a great need for more protected land in this region. Approximately $30 \%$ of the natural habitat in the area remains, and of that land, only $20 \%$ is protected. Ideally, all of the remaining area should be protected, but due to the needs of the local residents, a system of prioritization needs to occur (Ministère de l'Environnement, des Eaux et Forêts, 2003).

Further inland, the effects of human development has been devastating. Human activity in the center eco-region has reduced the natural habitat to only $5.5 \%$ of what it originally was, and less than $20 \%$ of that small amount of land is currently protected. Fires, cattle grazing, and illegal timber extraction continue to threaten this region (Ministère de l'Environnement, des Eaux et Forêts, 2003). Unfortunately, this is not the only region affected by fire and human practices.

The western eco-region is one of the driest regions and is commonly affected by slash and burn agriculture. The western region is so diverse that it could probably be divided into even smaller eco-regions, each completely distinct from the next. Five major types of soil are found there, which influences the flora and fauna that can grow in each area (Ministère de l'Environnement, des Eaux et Forêts, 2003). This area is extremely rich with endemic biodiversity. Yet Rabearivony, et al. (2010) pointed out that more effort is going into preserving the eastern rain forests and little is being done to preserve areas in the west. Currently, only $13 \%$ of the area's original vegetation remains, and as with other regions, approximately $20 \%$ of that is protected (Ministère de l'Environnement, des Eaux et Forêts, 2003). More positively, however, Rabearivony, et al. (2010) have proposed three new areas for conservation. These areas include forests, wetlands, freshwater lakes, rivers, and grasslands. In these areas, 334 species were observed, 243 of which are endemic to Madagascar. Within these endemic species are included; "44 reptiles, 54 amphibians, 104 birds, 23 small mammals, 17 lemurs, and one fish. Of these 243 species, 30 are considered endangered" (p. 35). One of the most notable endangered species is the Madagascar fish eagle, of which only 40 breeding pairs are left in the wild (Rabearivony, et al., 2010).

It is clear that Madagascar has significant conservation work to accomplish before it has achieved its goals. In 2003, the government of Madagascar committed to more than triple the area of the country's protected regions (Madagascar National Parks, 2010). 
However, what is more important to note is that the government of Madagascar is not alone in achieving its goal. Many private organizations such as the WWF, the Madagascar Fauna Group, and Operation Wallacea all contribute to the conservation efforts in Madagascar. Some obtain government funding. Yet, even with progression in conservation efforts, rates of deforestation have increased every year since 2000 (Rabearivony, et al., 2010).

\section{Opposition and Culture}

It is easy to judge the majority of the people in Madagascar for their lack of conservation ethic, but it should be remembered that Madagascar is a place of poverty. Almost $70 \%$ of the people in Madagascar live on less than $\$ 1.25$ a day. Including the wealthy, the average income in Madagascar is $\$ 410$ in a year (UNICEF). This poor standard of living is what has led to an overall lack of foresight in the country. This has led to practices of deforestation, over fishing, and illegal animal trading as a meagre source of income for many impoverished villagers.

Although it would be beneficial to biodiversity for the government of Madagascar to expand the current protected area in the country, the potential unfavourable effects on the local inhabitants must also be considered. Many tribes and villages only escape starvation and destituteness because of their reliance on the land. In these locations, little emphasis is placed on material wealth. Instead, the people have great joy in their families and posterity (Keller, 2008). They rely on the land to support their families and when that land is taken away, they are no longer able to support large families. Keller (2008) argues that some of the rural locals feel defeated when their land is turned into a national park. The government is aware of the opposition from some villages and is encouraging rural villages to help in the preservation and maintenance of parks by providing funding to schools and other needs of the people (Madagascar National Parks, 2010). Recent political instability and corruption, however, has affected Madagascar's tourism industry, which in turn limits the amount of conservation practices and strategies that the government can implement and accomplish.

\section{Conclusion}

Urgent international intervention is needed in helping with conservation efforts in Madagascar. The country has reasonable short term and long term goals for preserving 
its significant biodiversity. The people of Madagascar have tremendous potential for educating the world about their natural wonders. This can be achieved by working collaboratively with conservation experts, and by participating in maintaining their region's parks through local jobs, creating a level of financial stability within their villages. By establishing partnerships with various organizations, Madagascar's biodiverse eco-regions can be better protected, which can then enable conservationists and researchers to increase their knowledge about the significant species that exist in these regions.

* Author: Darren Joneson is a student at Grant MacEwan University.

\section{References}

Aguiar, J. (1998). Evanescent diversity--the palms of Madagascar. Bioscience, 48(7), pp. 499-503.

Andreone, F., Cadle, J., Cox, N., Glaw, F., Nussbaum, R., Raxworthy, C.,... Vences, M. (2005). Species review of amphibian extinction risks in Madagascar: Conclusions from the global amphibian assessment. Conservation Biology, 19(6), pp. 1790-1802. doi:10.1111/j.1523-1739.2005.00249.x.

Benstead, J., De Rham, P., Gattoliat, J., Sartori, M., Gibon, F., Loiselle, P.,...Stiassny, M. (2003). Conserving Madagascar's freshwater biodiversity. Bioscience, 53(11), 1101-1111.

Consiglio, T., Schatz, G., McPherson, G., Lowry II, P., Rabenantoandro, J., Rogers, Z.,... Rabehevitra, D. (2006). Deforestation and plant diversity of Madagascar's littoral forests. Conservation Biology, 20(6), 1799-1803. doi:10.1111/j.1523-1739.2006. 00562.x.

Karsten, K., Andrianmandimbiarisoa, L., Fox, S., \& Raxworthy, C. (2009). Population densities and conservation assessments for three species of chameleons in Toliara region of south-western Madagascar. Amphibia-Reptilia, 30(3), 341-350. doi:10.1163/156853809788795254.

Keller, E. (2008). The banana plant and the moon: Conservation and the Malagasy ethos of life in Masoala, Madagascar. American Ethnologist, 35(4), pp. 650-664. doi:10.111/j.1548-1425.2008.00103.x.

Madagascar Fauna Group (2010). Retrieved September 16, 2010, from http://www.savethelemur.org 
Madagascar National Parks (2010). The conservation. Retrieved September 9, 2010, from http://www.parcs-madagascar.com/madagascar-nationalparks_en.php?Navigation $=26$

Ministère de l'Environnement, des Eaux et Forêts (2003). Madagascar protected area system management plan. Retrieved September 2010, from http:/ /www.parcsmadagascar.com/madagascar-national-parks_en.php?Navigation=26

Mittermeier, R., Ganzhorn, J., Konstant, W., Glander, K., Tattersall, I., Groves. C.,... Rasoloarison, R. (2008). Lemur diversity in Madagascar. International Journal of Primatology, 29(6), 1607-1656. doi: 10.1007/s10764-008-9317-y.

Rabearivony, J., Thorstrom, R., de Roland, L., Rakotondratsima, M., Andriamalala, T., Sam, T.,... Rakotoson, M. (2010). Protected area surface extension in Madagascar: Do endemism and threatened species remain useful criteria for site selection?. Madagascar Conservation \& Development, 5(1), pp. 35-47.

Rickard, M. (1980). A new continental assembly for Pangea. Tectonophysics, 63(1-4), pp. 112.

UNICEF (2008). Economic indicators. Retrieved September 15, 2010, from http://www.unicef.org/infocountry/madagascar statistics.html 